Reviu Akuntansi dan Bisnis Indonesia, Vol. 4 No. 1, Hlm: 37-42, Juli 2020

Website: http://journal.umy.ac.id/index.php/rab

\title{
Pengaruh Pengendalian Internal dan Moralitas Individu Terhadap Kecurangan (Fraud) Akuntansi (Studi Eksperimen Pada Mahasiswa Universitas Muhammadiyah Riau)
}

Evelina Tampubolon', Siti Rodiah ${ }^{1 *}, \&$ Agustiawan $^{1}$

'Program Studi Akuntansi Universitas Muhammadiyah Riau

I N F O A R TIK EL

\section{Kata Kunci:}

Pengendalian Internal,

Moralitas Individu,

Kecurangan Akuntansi.

Jenis Artikel:

Penelitian Empiris

Korespondensi:

sitirodiah@umri.ac.id

\author{
A B S T R A K
}

\section{Latar Belakang:}

Kasus korupsi dari tahun ke tahun semakin marak yang mengakibatkan banyaknya ketertarikan dari penelitian terdahulu dalam menguji pengaruh pengendalian internal dan moralitas individu terhadap kecurangan akuntansi. Namun, dari beberapa hasil penelitian terdahulu masih ditemukan adanya gap empiris.

Tujuan:

Penelitian ini bertujuan untuk menguji pengaruh pengendalian internal dan moralitas individu terhadap kecurangan akuntansi.

\section{Metode Penelitian:}

Rancangan penelitian yang digunakan adalah eksperimen dengan desain faktorial 2x2 yang melibatkan 78 mahasiswa akuntansi Universitas Muhamadiyah Riau. Untuk menguji hipotesis dalam penelitian ini digunakan uji statistik Two Way Analysis of Variance (ANOVA).

\section{Hasil Penelitian:}

Hasil penelitian menunjukkan bahwa: terdapat perbedaan antara individu pada kondisi terdapat elemen Pengendalian Internal dan tidak terdapat elemen Pengendalian Internal dalam melakukan Kecurangan Akuntansi; terdapat perbedaan antara individu yang memiliki level Moralitas Individu tinggi dan level Moralitas Individu rendah dalam melakukan Kecurangan Akuntansi; dan terdapat interaksi antara Pengendalian Internal dengan Moralitas Individu dalam mempengaruhi Kecurangan Akuntansi.

Keterbatasan Penelitian:

Variabel independen yang digunakan dalam penelitian ini hanya mencakup Pengendalian Internal dan Moralitas Individu saja.

Keaslian/Novetly Penelitian:

Hasil penelitian ini penting dilakukan karena dapat membantu mahasiswa dalam memahami teori dalam akuntansi perilaku dan dapat membantu instansi terkait dalam mengurangi kecenderungan kecurangan dengan menerapkan pengendalian internal secara efektif.

(C) 2020 RAB. Published by Universitas Muhammadiyah Yogyakarta DOI: $10.18196 / \mathrm{rab} .040151$

\section{PENDAHULUAN}

Kecurangan akuntansi atau dalam pengauditan disebut dengan fraud, merupakan suatu tindakan kecurangan yang dilakukan individu dan kelompok yang bertujuan untuk memberikan 
keuntungan kepada individu atau kelompok tersebut. Association of Certified Fraud Examinations (ACFE Indonesia Chapter, 2018) mengklasifikasikan kecurangan akuntansi dalam tiga kategori utama yaitu kecurangan laporan keuangan (financial statement fraud), penyalahgunaan aset (asset misappropiation) dan korupsi (corruption). Berdasarkan klasifikasi tersebut, korupsi merupakan salah satu tindak kecurangan akuntansi yang sering terjadi di Indonesia. Selanjutnya, ACFE melakukan penelitian pada tahun 2016 hingga tahun 2018 dan menyatakan bahwa terjadi peningkatan jumlah persentase untuk kasus korupsi, dari 35,4\% menjadi 38\%. Menurut informasi yang didapat dari kontan.co.id, kasus korupsi yang terjadi di Indonesia sebanyak 454 kasus dengan jumlah tersangka 1.087 orang. Bukan hanya itu saja, Indonesia Corruption Watch (ICW) (2018) melaporkan kerugian negara atas kasus tersebut sebesar Rp. 5,6 triliun. Selain itu jumlah suap senilai Rp 134,7 miliar, untuk pungutan liar nilainya adalah 6,7 miliar dan jumlah pencucian uang sebesar Rp 91 miliar (Malau \& Simanjuntak, 2019).

Peningkatan kasus kecurangan di Indonesia, telah menarik banyak perhatian peneliti diantaranya adalah Dewi (2017) yang menemukan bahwa kecurangan akuntansi dipengaruhi oleh tiga hal (fraud triangle) yang terdiri dari pressure (tekanan), opportunity (kesempatan) dan rationalization (rasionalisasi). Tekanan yang dimaksud adalah tekanan dari pihak manajemen dan kondisi ekonomi karyawan itu sendiri, kesempatan yang berarti terdapat situasi dalam instansi untuk melakukan kecurangan dan sikap rasionalisasi menunjukan sikap karyawan yang merasionalisasikan aksi ketidakjujuran mereka dengan menganggap perbuatannya masih bisa diterima (Eka Putra \& Latrini, 2018). Sehingga untuk menangani kecurangan akuntansi yang mungkin terjadi dalam suatu instansi, maka perlu adanya pengendalian internal yang efektif.

Eka Putra \& Eka Putra \& Latrini (2018) menguji pengaruh sistem pengendalian internal terhadap kecurangan akuntansi dan menemukan bahwa sistem pengendalian internal berpengaruh negatif terhadap kecurangan akuntansi. Begitu juga dengan penelitian Abiola \& Adedokun (2013) yang menemukan bahwa terdapat hubungan yang kuat dan signifikan antara sistem pengendalian internal dengan pendeteksian kecurangan dan Rodiah, Ardianni, \& Herlina, (2019) yang menemukan bahwa pengendalian internal berpengaruh negatif terhadap kecurangan akuntansi. Namun, hasil penelitian di atas tidak sejalan dengan penelitian Fitri, Nurazlina, \& A (2016) yang menyatakan bahwa pengendalian internal tidak berpengaruh terhadap kecurangan akuntansi dan banyaknya kecurangan akuntansi yang terjadi lebih dipengaruhi oleh kualitas moral seseorang. Hal ini menunjukkan bahwa pengendalian internal (ada dan tidak adanya pengendalian internal) tidak berpengaruh terhadap kecurangan akuntansi.

Pernyataan Fitri, Nurazlina, \& A (2016) terkait kualitas moral seseorang sebelumnya telah diuji oleh beberapa peneliti diantaranya adalah Maroney \& McDevitt (2008) yang menemukan individu yang memiliki moralitas tinggi, segala tindakannya akan diatur oleh prinsip moralitas universal. Hal ini berarti individu yang bermoralitas tinggi tidak akan melakukan kecurangan. Hasil ini berbeda dengan penelitian yang dilakukan Astuti, Sujana, \& Purnamawati (2017) dan menemukan bahwa moralitas individu tidak berpengaruh terhadap kecurangan akuntansi. Mazar, Amir, \& Ariely (2008) menyatakan bahwa ketika seseorang memiliki kesempatan untuk berbuat curang maka mereka akan melakukannya tetapi tingkat ketidakjujurannya relatif rendah. Ini menunjukan bahwa individu dengan moral yang tinggi maupun rendah akan melakukan kecurangan saat ada kesempatan.

Berdasarkan permasalahan yang telah disampaikan di awal dan masih ditemukan adanya gap empiris antar penelitian Rodiah, Ardianni, \& Herlina, (2019), dengan Fitri, Nurazlina, \& A (2016) terkait pengaruh pengendalian iternal terhadap kecurangan akuntansi, serta penelitian (Dewi, 2017) dengan (Mulia et al., 2017) terkait moralitas individu terhadap kecurangan akuntansi, maka penelitian ini bertujuan untuk menguji kembali penelitian Dewi (2017) tentang pengaruh moralitas individu dan pengendalian internal terhadap kecurangan akuntansi dengan menggunakan metode eksperimen pada Satuan Kerja Perangkat Daerah (SKPD) di tingkat sekretariat daerah. Perbedaan penelitian Dewi (2017) dengan penelitian ini terletak pada sampel yang digunakan. Dewi (2017) menggunakan sampel Satuan Kerja Perangkat Daerah (SKPD) di tingkat Sekretariat Daerah, sedangkan penelitian ini menggunakan mahasiswa program studi akuntansi Unversitas Muhammadiyah Riau. Alasan pemilihan mahasiswa sebagai partisipan penelitian ini dikarenakan mahasiswa adalah wakil atau pengganti yang sesuai untuk menggantikan peran sebagai pejabat 
pengadaan dan staf bagian akuntansi dan pelaporan dalam penelitian pembuatan keputusan dan pertimbangan (Clinton, 1999), (Cheng dkk., 2003) dalam (Rodiah \& Nahartyo, 2019).

\section{TINJAUAN LITERATUR DAN PERUMUSAN HIPOTESIS}

\section{Teori Fraud Triangle}

Fraud triangle adalah sebuah teori yang dikemukakan oleh Donald R. Cressey setelah melakukan penelitian untuk tesis doktor-nya pada tahun 1950. Cressey mengemukakan hipotesis mengenai fraud triangle untuk menjelaskan alasan mengapa orang melakukan kecurangan (fraud). Berdasarkan penelitian yang dilakukan, Cressey (1950) menemukan bahwa orang melakukan fraud ketika mereka memiliki masalah keuangan yang tidak bisa diselesaikan bersama, tahu dan yakin bahwa masalah tersebut bisa diselesaikan secara diam-diam dengan jabatan/pekerjaan yang mereka miliki dan mengubah pola pikir dari konsep mereka sebagai orang yang dipercayai memegang aset menjadi konsep mereka sebagai pengguna dari aset yang dipercayakan kepada mereka. Cressey juga menambahkan bahwa banyak dari pelanggar kepercayaan ini mengetahui bahwa tindakan yang mereka lakukan merupakan tindakan yang ilegal, tetapi mereka berusaha memunculkan pemikiran bahwa apa yang mereka lakukan merupakan tindakan yang wajar. Dari penjelasan di atas, Cressey mengungkapkan bahwa ada 3 faktor yang mendukung seseorang melakukan fraud, yaitu pressure (dorongan), opportunity (peluang), dan rationalization (rasionalisasi).

\section{Pengaruh Pengendalian Internal terhadap Kecurangan Akuntansi}

Teori Fraud Triangle menyebutkan bahwa ada tiga faktor penyebab terjadinya kecurangan, yaitu opportunity, pressure, dan rationalization (Cressey, 1950). Dari ketiga elemen Fraud Triangle, kesempatan terbesar dalam mengendalikan fraud terdapat pada elemen opportunity. Elemen opportunity yang dapat memicu tindak kecurangan berasal dari pengendalian internal suatu organisasi yang lemah, kurangnya pengawasan, dan/atau penyalahgunaan wewenang (Cressey, 1950), sehingga manajemen sangat perlu untuk mengendalikan terjadinya fraud, dengan cara melakukan pengendalian internal yang efektif (Wilopo, 2006). Coram, Ferguson, \& Moroney (2008) menyatakan bahwa organisasi yang memiliki fungsi audit internal akan lebih mudah untuk mendeteksi kecurangan akuntansi. Hal ini dikarenakan pengendalian internal yang baik akan menurunkan tingkat kecenderungan kecurangan akuntansi yang mungkin terjadi (Eka Putra \& Latrini, 2018).

Penelitian Eliza (2015) menyatakan bahwa pengendalian internal berpengaruh negatif dan signifikan terhadap tingkat kecenderungan kecurangan akuntansi pada SKPD kota Padang. Pengendalian internal dapat mengurangi kecurangan akuntansi (Rodiah et al., 2019). Pengendalian internal yang efektif, memungkinkan terjadinya pengecekan silang (cross check) terhadap pekerjaan seseorang oleh orang lain. Hal ini berarti pengendalian internal yang baik dapat mengurangi bahkan menutup peluang untuk melakukan kecurangan akuntansi. Sebaliknya, pada saat pengendalian internal sebuah perusahaan tidak berjalan efektif, maka hal ini akan membuat sebuah peluang (opportunity) seseorang dalam melakukan kecurangan (Cressey, 1950). Oleh sebab itu, dalam sebuah perusahaan sangat dibutuhkan monitoring untuk memastikan pengendalian internal sudah berjalan dengan efektif atau belum sehingga kecuranngan dapat dikurangi bahkan dihilangkan dalam perusahaan. Berdasarkan penjelasan di atas, maka dapat dirumuskan hipotesis sebagai berikut:

$\mathbf{H}_{1}$ : Terdapat perbedaan antara individu pada kondisi terdapat elemen pengendalian internal dan tidak terdapat elemen pengendalian internal dalam melakukan kecurangan (fraud) akuntansi. 


\section{Pengaruh Moralitas Individu terhadap Kecurangan Akuntansi}

Teori perkembangan moral Kohlberg (1994) menyatakan bahwa moral berkembang melalui tiga tahapan, yaitu tahapan pre-conventional, tahapan conventional dan tahapan post-conventional. Semakin tinggi level penalaran moral individu, maka akan semakin cenderung untuk tidak melakukan kecurangan akuntansi (Wilopo, 2006). Welton \& Lagrone (1994) menyatakan bahwa kemampuan individu dalam menyelesaikan dilema etika dipengaruhi oleh level penalaran moralnya.

Penelitian Fitri, Nurazlina, \& A (2016) menyatakan moralitas individu berpengaruh terhadap kecenderungan kecurangan akuntansi. Hasil penelitian ini mendukung teori tahap perkembangan moral Kohlberg (1994) yang menyatakan bahwa semakin tinggi tahapan moralitas individu, maka individu tersebut akan semakin memperhatikan kepentingan orang banyak daripada kepentingan pribadi bahkan organisasinya sendiri sehingga individu tersebut akan selalu berusaha menghindarkan diri dari kecenderungan untuk melakukan kecurangan akuntansi yang akan merugikan banyak orang (Sholehah et al., 2018).

Namun hasil penelitian di atas tidak sejalan dengan hasil penelitian Astuti et al. (2017) yang menyatakan bahwa moralitas individu tidak berpengaruh signifikan terhadap kecurangan akuntansi pada LPD di Kabupaten Buleleng. Rodiah et al. (2019) menyatakan semakin tinggi tahapan moralitas manajemen (tahapan pasca-konvensional), semakin manajemen memperhatikan kepentingan yang lebih luas dan universal dari pada kepentingan perusahaan semata, terlebih kepentingan pribadinya. Oleh karenanya, semakin tinggi moralitas manajemen, semakin manajemen berusaha menghindarkan diri dari kecenderungan kecurangan akuntansi. Berdasarkan penjelasan di atas, maka dapat dirumuskan hipotesis sebagai berikut:

$\mathbf{H}_{2}$ : Terdapat perbedaan antara individu yang memiliki level moralitas tinggi dan level moralitas rendah dalam melakukan kecurangan akuntansi.

\section{Pengaruh Pengendalian Internal dan Moralitas Individu terhadap Kecurangan Akuntansi}

Hernandez \& Groot (2007) menunjukkan hasil penelitian bahwa lingkungan pengendalian akuntansi dan etika seseorang merupakan dua hal yang saling berkaitan dengan kecenderungannya dalam melakukan suatu kecurangan akuntansi. Berbagai temuan yang telah dipaparkan berdasarkan kasus-kasus kecurangan akuntansi di Indonesia menunjukkan bahwa faktor penyebab kecurangan akuntansi dapat dibedakan menjadi faktor perusahaan (eksternal) dan faktor dalam diri individu (internal) sebagai pelaku.

Penelitian yang dilakukan Dewi (2017) pada Pemerintah Daerah Provinsi Bali menemukan bahwa terdapat interaksi antara moralitas individu dan pengendalian internal terhadap kecenderungan kecurangan akuntansi. Kondisi elemen pengendalian internal di dalam organisasi (ada dan tidak ada pengendalian internal) dapat mempengaruhi individu dengan level moral rendah untuk cenderung melakukan atau tidak melakukan tindak kecurangan akuntansi. Namun bagi individu dengan level moral tinggi, kondisi ada dan tidak adanya pengendalian internal organisasi tidak akan membuatnya melakukan kecurangan akuntansi yang akan merugikan organisasi dan masyarakat. Namun logika ini tidak sejalan dengan pendapat (Cressey, 1950) tentang segitiga kecurangan. Cressey mengatakan bahwa kecurangan akuntansi terjadi karena adanya tekanan, kesempatan dan rasionalisasi. Moralitas tidak menjadi pendorong kecurangan, karena setiap pelaku kecurangan tidak pernah mencerap terlanggarnya prinsip moralitasnya. Namun, riset Mazar et al. (2008) mengindikasikan bahwa moralitas bisa mencegah kecurangan dan berinteraksi dengan pengendalian internal untuk mempengaruhi kecurangan individu Berdasarkan penjelasan di atas, maka dapat dirumuskan hipotesis sebagai berikut:

$\mathbf{H}_{3}$ : Terdapat interaksi antara pengendalian internal dan moralitas individu terhadap kecurangan akuntansi. 


\section{METODE PENELITIAN}

\section{Desain Penelitian}

Penelitian ini merupakan penelitian eksperimen dengan desain faktorial 2x2 antar subjek untuk menguji pengaruh pengendalian internal dan moralitas individu pada kecurangan akuntansi. Penelitian eksperimen menurut Sekaran (2009) menguji kemungkinan hubungan sebab-akibat di antara variabel, berbeda dengan studi korelasional, yang menguji hubungan antar variabel tanpa perlu mencoba menetapkan apakah satu variabel menyebabkan variabel lain.

\section{Partisipan}

Partisipan pada penelitian ini adalah mahasiswa Fakultas Ekonomi dan Bisnis Jurusan Akuntansi dengan kriteria telah menempuh mata kuliah auditing 1 dan auditing 2 serta telah bekerja. Alasan pemilihan mahasiswa sebagai sampel penelitian ini dikarenakan mahasiswa adalah wakil atau pengganti yang sesuai untuk menggantikan peran sebagai pejabat pengadaan dan staf bagian akuntansi dan pelaporan dalam penelitian pembuatan keputusan dan pertimbangan (Clinton, 1999), (Cheng dkk., 2003) dalam (Rodiah \& Nahartyo, 2019).

\section{Prosedur dan Skenario Eksperimen}

Sebelum partisipan memulai eksperimen, eksperimenter membagikan angket yang harus diselesaikan oleh partisipan. Eksperimenter melarang partisipan untuk membuka angket tersebut sebelum peneliti selesai menjelaskan sedikit mengenai kecurangan akuntansi dan petunjuk pengisian angket. Tujuan eksperimenter menjelaskan kecurangan akuntansi adalah untuk memastikan agar partisipan memahami dengan benar tugas yang akan dikerjakannya.

Kemudian, eksperimenter meminta partisipan untuk membuka instrumen dan menghitung apakah jumlah halaman dalam instrumen tersebut telah sama dengan instrumen yang telah diterima oleh partisipan lainnya. Selama eksperimen tersebut berlangsung, eksperimenter akan memandu jalannya eksperimen dengan mengarahkan partisipan untuk membuka dan menyelesaikan kasus tersebut dengan waktu yang bersamaan.

Angket diberikan kepada partisipan terdiri dari dua bagian. Bagian pertama berisi sebuah kasus dan bagian kedua berisi pertanyaan mengenai kasus tersebut. Terkait pengendalian internal partisipan diminta berperan sebagai pejabat pengadaan yang mendapat tugas untuk melaksanakan pengadaan langsung barang atau jasa dalam Unit Layanan Pengadaan (ULP) di Universitas X. Kemudian partisipan diperintahkan untuk menjawab beberapa pertanyaan sesuai dengan apa yang dirasakan oleh partisipan.

Terkait moralitas individu partisipan diminta untuk berperan sebagai staf bagian akuntansi dan keuangan yang dihadapkan tentang dilema etika. Partisipan kemudian diberi pertanyaan-pertanyaan untuk mengukur level penalaran moralitas individu tersebut berdasarkan skor yang diperoleh. Kemudian, di halaman selanjutnya terdapat dua pertanyaan yang ditujukan sebagai cek manipulasi untuk memastikan bahwa semua partisipan memperhatikan kasus dan peran yang diberikan kepada mereka.

Setelah mendapatkan data dan informasi yang dibutuhkan, kemudian hasilnya diolah dan selanjutnya diproses berdasarkan teori-teori yang telah dipelajari. Sementara itu proses analisis dilakukan dengan pendekatan kuantitatif menggunakan metode statistik yang relevan.

\section{Definisi Operasional Variabel}

\section{Variabel Terikat (Dependence Variable)}

Variabel terikat (dependence variable) adalah variabel yang menjadi perhatian utama dalam penelitian dan menjadi faktor yang berlaku dalam investigasi. Analisis dilakukan pada variabel 
terikat untuk menemukan solusi pada masalah yang diteliti (Sekaran, 2009). Variabel terikat yang digunakan dalam penelitian ini adalah kecurangan akuntansi.

Variabel kecurangan akuntansi diukur dengan meminta partisipan untuk memberikan pendapatnya dalam pertanyaan kasus mengenai pengadaan barang/jasa. Partisipan menjawab pertanyaan tersebut setelah membaca skenario eksperimen. Skala likert 1-10 digunakan untuk mengukur respons dari partisipan. Semakin tinggi partisipan memberikan angka penilaiannya, semakin cenderung partisipan tersebut melakukan kecurangan.

\section{Variabel Bebas (Independence Variable)}

\section{Pengendalian Internal}

Pengukuran variabel pengendalian internal menggunakan soal kasus yang terdiri atas dua kondisi, yaitu terdapat elemen pengendalian internal dan tidak terdapat pengendalian internal. Kondisi adanya elemen pengendalian internal digambarkan melalui adanya penerapan wewenang dan tanggung jawab di organisasi, pencatatan transaksi berkala, adanya pengendalian fisik, sistem akuntansi yang komprehensif, serta pemantauan dan evaluasi berkala. Kondisi tidak adanya elemen pengendalian internal digambarkan berupa tidak adanya penerapan wewenang dan tanggung jawab yang jelas di organisasi, pencatatan transaksi yang tidak berkala, tidak adanya pengendalian fisik, sistem akuntansi yang tidak dapat mencatat seluruh kegiatan operasional instansi serta tidak adanya pemantauan dan evaluasi secara berkala di dalam instansi.

\section{Moralitas Individu}

Pengukuran moralitas berasal dari model pengukuran moral oleh Kohlberg (1994) dalam bentuk instrumen Defining Issues Test Test (DIT) yang dirancang untuk mengukur kapasitas moral kognitif, yaitu tingkat penalaran moral yang mampu dilakukan oleh seorang individu. Moralitas diukur melalui 6 butir instrumen yang mengukur setiap tahapan moralitas melalui kasus dilema etika akuntansi. Setiap tahapan moralitas ditunjukkan dengan skala satu sampai dengan empat, selanjutnya dilakukan penjumlahan hasil skala dari keenam instrumen tersebut. Hasil pengukuran atas dilema etika akuntansi ini merupakan cerminan moralitas individu. Semakin rendah hasil penjumlahan skala dari instrumen tersebut, maka tingkat moralitas individu tersebut masih berada pada tahap yang rendah yaitu level pre-conventional.

\section{Jenis dan Sumber Data}

Data dalam penelitian ini terdiri dari data kuantitatif dan data kualitatif yang dikuantitatifkan agar dapat diproses lebih lanjut dalam statistik (Mudrajad, 2013). Sumber data yang digunakan dalam penelitian ini adalah data primer, data yang didapatkan dengan melakukan penelitian langsung terhadap subjek penelitian, dengan cara menggunakan angket, kasus, kuesioner, dan lainnya (Mudrajad, 2013).

\section{Teknik Analisis Data}

Teknik analisis data yang digunakan dalam penelitian ini yaitu statistik deskriptif dan analysis of variance (ANOVA). Salah satu syarat untuk analysis of variance (ANOVA) adalah data memenuhi uji asumsi klasik. Uji asumsi klasik dilakukan untuk mendapatkan keyakinan bahwa data dalam penelitian valid untuk diolah lebih lanjut menggunakan ANOVA (Mudrajad, 2013).

\section{Statistik Deskriptif}

Analisis statistik deskriptif ditujukan untuk memberikan gambaran umum mengenai partisipan yang dijelaskan dalam tabel distribusi frekuensi. Tabel tersebut berguna untuk menunjukkan 
demografi partisipan, sedangkan deskripsi mengenai variabel-variabel penelitian menggunakan tabel distribusi frekuensi yang menunjukan kisaran teoritis, kisaran sesungguhnya, mean dan standar deviasi yang diperoleh dari hasil jawaban partisipan.

\section{Uji Normalitas}

Screening terhadap normalitas data merupakan langkah awal yang harus dilakukan untuk setiap analisis multivariate (Ghozali, 2013).Uji kolmogorov smirnow adalah pengujian normalitas yang banyak digunakan dalam penelitian.

\section{Uji Homogenitas}

Homogeneity of variance yaitu variabel dependen harus memiliki varian yang sama dalam setiap kategori variabel independen (Ghozali, 2013). Jika terdapat lebih dari satu variabel independen, maka harus ada homogeneity of variance di dalam cell yang dibentuk oleh variabel independen kategorikal. SPSS memberikan test ini dengan nama Levene's Test of Homogeneity of Variance.

\section{Uji Hipotesis}

Untuk pengujian hipotesis dilakukan melalui uji statistik Two Way Analysis of Variance Test of Between Subjects dengan program SPSS versi 20.0. Penelitian ini menggunakan Two-Way Anova untuk mengetahui pengaruh variabel independen berskala data kategorik yaitu variabel pengendalian internal (ada dan tidak elemen pengendalian internal) dan variabel moralitas individu (tinggi dan rendah tingkat moralitas individu) terhadap satu variabel dependen berskala data kuantitatif/numerik yaitu variabel kecurangan akuntansi, serta pengaruh pengendalian internal dan moralitas individu terhadap kecurangan akuntansi (Ghozali, 2013).

\section{HASIL DAN PEMBAHASAN}

\section{Pilot Test}

Tujuan diadakannya pilot test adalah untuk mengetahui validitas prosedur eksperimen, presisi desain eksperimen serta kemungkinan untuk perbaikan instrumen dan diharapkan eksperimen berjalan dengan baik. Evaluasi hasil pilot test berupa perbaikan pada tata bahasa agar lebih mudah dipahami oleh partisipan. Dari 20 partisipan pilot test yang lulus cek manipulasi sebanyak 17 orang.

\section{Hasil Uji Statistik Deskriptif}

Tabel 1

Statistik Deskriptif

Descriptive Statistics

\begin{tabular}{llrrr}
\hline Pengendalian Internal & Moralitas Individu & Mean & Std. Deviation & N \\
& Tinggi & 2,90 & 1,447 & 20 \\
Ada & Rendah & 2,95 & 1,638 & 20 \\
& Total & 2,93 & 1,526 & 40 \\
\multirow{2}{*}{ Tidak Ada } & Tinggi & 2,45 & 1,572 & 20 \\
& Rendah & 5,89 & 2,298 & 18 \\
& Total & 4,08 & 2,593 & 38 \\
Total & Tinggi & 2,68 & 1,509 & 40 \\
& Rendah & 4,34 & 2,453 & 38 \\
& Total & 3,49 & 2,179 & 78 \\
\hline
\end{tabular}

Dependent Variable: Kecurangan Akuntansi

Sumber: Data Olahan, 2020 
Uji statistik deskriptif memberikan gambaran atau deskripsi suatu data dilihat dari mean, minimum, maximum, dan standard deviation.

\section{Uji Normalitas}

Uji normalitas dilakukan untuk mengetahui apakah data dalam penelitian ini terdistribusi dengan normal. Hasil pengujian normalitas dengan kolmogorov-smirnov test menunjukan nilai asymp. sig 0,125>0,05 maka data terdistribusi dengan normal.

Tabel 2

Uji Normalitas

One-Sample Kolmogorov-Smirnov Test

\begin{tabular}{lll}
\hline & & $\begin{array}{l}\text { Standardized Residual for } \\
\text { Kecurangan_Akuntansi }\end{array}$ \\
\hline $\mathrm{N}$ & Mean & 78 \\
Normal Parameters &, 0000 \\
& Std. Deviation &, 98033 \\
Most Extreme Differences & Absolute &, 133 \\
& Positive &, 133 \\
Kolmogorov-Smirnov $\mathrm{Z}$ & Negative &,- 090 \\
Asymp. Sig. (2-tailed) & & 1,178 \\
\hline
\end{tabular}

a. Test distribution is Normal.

b. Calculated from data.

Sumber: Data Olahan. 2020

\section{Hasil Uji Homogenitas}

Levene's Test dilakukan untuk mengetahui apakah keempat perlakuan mempunyai varian yang sama. Hasil uji homogenitas ini menunjukkan nilai levene's statistic sebesar 0,104 $\geq 0,05$. Hal ini menunjukkan bahwa setiap kelompok subjek memenuhi varian yang sama.

Tabel 3

Uji Homogenitas

\begin{tabular}{llll}
\hline F & df1 & df2 & Sig. \\
\hline 2,131 & 3 & 74 &, 104 \\
\hline
\end{tabular}

Sumber: Data Olahan. 2020

\section{Hasil Uji Hipotesis}

Tahap akhir analisis dalam penelitian ini adalah melakukan pengujian data yang mengacu pada hipotesis penelitian yang diajukan. Pengujian hipotesis-hipotesis penelitian menggunakan Two Way Analysis of Variance (ANOVA) dan dilakukan pada batas signifikansi 5\% atau dengan tingkat kepercayaan $95 \%$. 
Tabel 3

Uji Hipotesis

\begin{tabular}{lcrrr}
\hline \multicolumn{1}{c}{ Source } & df & Mean Square & \multicolumn{1}{c}{ F } & \multicolumn{1}{c}{ Sig. } \\
\hline Corrected Model & 3 & 46,003 & 14,965 &, 000 \\
Intercept & 1 & 979,417 & 318,611 &, 000 \\
Pengendalian_Internal & 1 & 30,136 & 9,803 &, 002 \\
Moralitas_Individu & 1 & 59,217 & 19,264 &, 000 \\
$\quad$ Pengendalian_Internal * & 1 & 55,871 & 18,175 &, 000 \\
$\quad$ Moralitas_Individu & 74 & 3,074 & & \\
Error & 78 & & & \\
Total & 77 & & & \\
Corrected Total & & &
\end{tabular}

R Squared $=, 378$

(Adjusted R Squared = ,352)

Sumber: Data Olahan, 2020

Hasil analisis pada Tabel 3 di atas menunjukkan bahwa nilai koefisien sig. untuk hipotesis 1, 2, dan 3 seluruhnya lebih kecil dari nilai alpha yang ditetapkan yaitu 0,05. Dengan demikian dapat disimpulkan bahwa hipotesis 1,2 dan 3 diterima.

Kemuadian, untuk melihat adanya interaksi dapat dilihat dari pertemuan garis yang ditunjukkan oleh grafik pada Gambar 1. Seseorang dengan level moralitas yang tinggi akan cenderung lebih stabil untuk tidak melakukan kecurangan (fraud) akuntansi saat berada dalam kondisi ada atau tidak ada pengendalian internal. Hal tersebut dapat dilihat pada garis berwarna biru. Sementara itu, seseorang dengan level moralitas individu yang rendah memiliki kecenderungan melakukan kecurangan (fraud) akuntansi yang lebih tinggi saat berada pada kondisi tidak ada elemen pengendalian internal. Hal tersebut ditunjukkan oleh garis berwarna hijau.

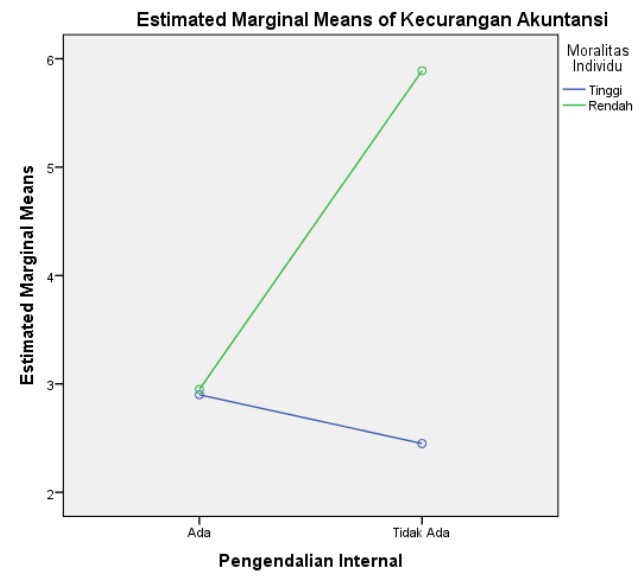

Gambar 1. Profile Plots Interaksi

\section{Pembahasan}

Hasil penelitian ini mendukung hipotesis pertama (H1) bahwa terdapat perbedaan antara individu yang berada dalam kondisi terdapat elemen pengendalian internal dan tidak terdapat elemen pengendalian internal dalam melakukan kecurangan (fraud) akuntansi tanpa memperhatikan perlakuan lainnya. Hal tersebut dibuktikan dari nilai koefisien signifikansi H1 sebesar 0,002 < 0,005 yang berarti hipotesis (H1) diterima. Berdasarkan hasil eksperimen ditemukan bahwa partisipan dengan kondisi terdapat pengendalian internal cenderung memilih untuk tidak melakukan kecurangan akuntansi. Hal ini dapat dilihat dari hasil persentase komponen varian antar kelompok dari variabel independen Pengendalian Internal adalah $8.245 \%$ hal ini 
berarti bahwa variabel independen Pengendalian Internal memiliki efek terhadap kecenderungan seseorang melakukan kecurangan (fraud) akuntansi sebesar $8.245 \%$ secara sendiri tanpa memperhitungkan variabel Moralitas Individu.

Berdasarkan hasil eksperimen yang dilakukan maka dinyatakan bahwa ketika terdapat elemen pengendalian Internal dalam organisasi, individu cenderung tidak melakukan kecurangan akuntansi karena adanya penerapan wewenang dan tanggung jawab di organisasi, pencatatan transaksi berkala, adanya pengendalian fisik, sistem akuntansi yang komprehensif, serta pemantauan dan evaluasi berkala. Kondisi tidak adanya elemen pengendalian internal digambarkan berupa tidak adanya penerapan wewenang dan tanggung jawab yang jelas di organisasi, pencatatan transaksi yang tidak berkala, tidak adanya pengendalian fisik, sistem akuntansi yang tidak dapat mencatat seluruh kegiatan operasional instansi serta tidak adanya pemantauan dan evaluasi secara berkala di dalam instansi.. Hasil penelitian ini mendukung penelitian sebelumnya oleh Dewi (2017), Eka Putra \& Latrini (2018) yaitu bahwa semakin efektif pengendalian internal yang ada di perusahaan semakin rendah kecenderungan seseorang melakukan kecurangan akuntansi dalam perusahaan. Oleh sebab itu, dengan dibentuknya peraturan dalam suatu organisasi sebagai salah satu bentuk pengendalian internal maka tujuan organisasi akan lebih mudah tercapai.

Selanjutnya, hasil penelitian ini juga mendukung hipotesis kedua (H2) bahwa terdapat perbedaan antara individu yang memiliki level Moralitas Individu tinggi dan level Moralitas Individu rendah dalam melakukan kecurangan (fraud) akuntansi tanpa memperhatikan perlakuan lainnya. Hal tersebut dibuktikan dari nilai koefisien signifikansi $\mathrm{H} 2$ sebesar $0,000<0,005$ yang berarti hipotesis kedua (H2) diterima. Pada Tabel 4.2 yang berisi statistik deskriptif data variabel dari empat grup eksperimen menunjukkan bahwa grup 3 dan grup 4 dengan partisipan yang memiliki level moralitas rendah, menghasilkan nilai mean yang lebih tinggi yaitu 2.95 dan 5.89 dibandingkan dengan mean grup 1 dan grup 2 dengan partisipan yang memiliki level moralitas tinggi yaitu 2.90 dan 2.68. Hal ini berarti kecenderungan seseorang melakukan kecurangan akuntansi akan lebih tinggi dilakukan oleh orang dengan level moralitas individu rendah dibandingkan dengan yang memiliki level moralitas individu tinggi.

Teori tahap perkembangan moral (Kohlberg, 1994) menyatakan bahwa semakin tinggi tahapan Moralitas Individu maka individu tersebut akan semakin memperhatikan kepentingan orang banyak daripada kepentingan pribadi atau organisasinya sendiri sehingga berusaha untuk menghindarkan diri dari kecenderungan untuk melakukan kecurangan akuntansi yang merugikan banyak orang. Hasil penelitian ini sekaligus memperkuat hasil dari penelitian-penelitian etika yang sebelumnya dilakukan oleh Coram et al. (2008), Fitri, Nurazlina, \& A (2016), Sholehah et al., (2018) bahwa seseorang dengan level penalaran Moralitas Individu yang tinggi akan cenderung melakukan perbuatan yang etis karena sensitif terhadap isu-isu etika. Persentase komponen varian antar kelompok dari variabel independen Moralitas Individu adalah $16.202 \%$ yang merupakan efek variabel independen Moralitas Individu terhadap kecenderungan seseorang melakukan kecurangan (fraud) akuntansi secara sendiri tanpa memperhitungkan kondisi Pengendalian Internal.

Hasil penelitian ini mendukung hipotesis ketiga (H3) bahwa terdapat interaksi antara Pengendalian Internal dengan level Moralitas Individu. Hasil penelitian menunjukkan pengaruh variabel interaksi dilihat dari nilai koefisien signifikansi sebesar $0.000<0,005$ yang menunjukkan bahwa terdapat ketergantungan antara kondisi elemen Pengendalian Internal dan level Moralitas Individu. Seseorang dengan level Moralitas Individu rendah cenderung mudah melakukan kecurangan akuntansi saat berada dalam kondisi tidak terdapat elemen Pengendalian Internal sedangkan seseorang dengan level Moralitas Individu tinggi cenderung stabil baik dalam kondisi terdapat elemen Pengendalian Internal maupun tidak terdapat elemen Pengendalian Internal. Perubahan kondisi elemen Pengendalian Internal (ada dan tidak adanya elemen Pengendalian Internal) akan mengakibatkan dampak perubahan pada individu dengan level moral tertentu (tinggi atau rendah) untuk melakukan kecurangan.

Hal itu dapat dilihat dari nilai mean grup 4 sebesar 5.89 dan grup 2 sebesar 2.45 yang menunjukkan bahwa terdapat perbedaan yang signifikan antara kedua grup tersebut yaitu sebesar 0,000. Seseorang dengan level penalaran moral rendah (grup 4) lebih cenderung melakukan tindakan kecurangan akuntansi dibandingkan dengan seseorang dengan level penalaran moral tinggi 
(grup 2) saat berada dalam kondisi tidak terdapat pengendalian internal. Hasil ini sesuai dengan teori yang dikemukakan oleh Kohlberg (1994) bahwa orang dengan level penalaran moral rendah (level pre-conventionel) memanfaatkan kondisi tidak terdapat Pengendalian Internal untuk memenuhi kebutuhan pribadinya, seperti melakukan kecurangan akuntansi. Hernandez \& Groot (2007) mengatakan bahwa pengendalian dan etika seseorang merupakan dua hal yang saling berkaitan dengan kecenderungannya dalam melakukan suatu kecurangan akuntansi.

Berdasarkan hasil eksperimen penelitian diketahui bahwa kondisi elemen Pengendalian Internal di dalam organisasi (ada dan tidak ada Pengendalian Internal) dapat mempengaruhi individu dengan level moral rendah untuk cenderung melakukan atau tidak melakukan tindak kecurangan akuntansi. Namun bagi individu dengan level moral tinggi, kondisi ada dan tidak adanya Pengendalian Internal organisasi tidak akan membuatnya melakukan kecurangan akuntansi yang akan merugikan organisasi dan masyarakat. Hal tersebut ditunjukan dengan nilai mean Grup 4 sebesar 5.89 dan nilai mean Grup 3 sebesar 2.95 yang memiliki perbedaan signifikan sebesar 0,000. Hasil penelitian ini mendukung penelitian dari Dewi (2017) bahwa seseorang dengan level penalaran moral rendah akan lebih memperhatikan sanksi hukum yang mungkin diterima sehingga saat berada dalam kondisi terdapat elemen Pengendalian Internal ia tidak akan melakukan hal yang menyebabkan dirinya diberi hukuman. Hasil analisis varian desain faktorial menunjukkan bahwa sebesar $37.760 \%$ varian pada variabel dependen Kecurangan Akuntansi disebabkan oleh variasi atau perbedaan pada nilai variabel independen yaitu kondisi elemen Pengendalian Internal (ada dan tidak ada) dan tingkat Moralitas Individu (tinggi atau rendah) secara bersama-sama sedangkan sebesar $62.240 \%$ tidak dapat dijelaskan oleh model.

\section{KESIMPULAN}

Berdasarkan hasil analisis yang dilakukan dalam penelitian ini, terdapat beberapa kesimpulan sebagai berikut; Terdapat perbedaan kecenderungan seseorang dalam melakukan kecurangan ketika ada pengendalian internal dan tidak ada pengendalian internal. Terdapat perbedaan antara individu yang memiliki level Moralitas Individu tinggi dan level Moralitas Individu rendah dalam melakukan kecurangan (fraud) akuntansi tanpa memperhatikan perlakuan lainnya. Adanya perbedaan kecenderungan melakukan kecurangan akuntansi antara individu dengan level Moralitas Individu rendah dan tinggi dalam kondisi ada dan tidak adanya elemen Pengendalian Internal. Sementara itu, seseorang yang memiliki level Moralitas Individu tinggi cenderung tidak melakukan Kecurangan Akuntansi baik dalam kondisi terdapat maupun tidak terdapat elemen Pengendalian Internal.

\section{DAFTAR PUSTAKA}

Abiola, I., \& Adedokun, T. O. (2013). Internal Control System on Fraud Detection. Journal of Accounting and Finance, 13.

ACFE Indonesia Chapter. (2018). Survai Fraud Indonesia. ACFE Indonesia Chapter, 1-66. https://doi.org/10.1201/9781315178141-3

Astuti, N. K. A. T., Sujana, E., \& Purnamawati, I. G. A. (2017). Pengaruh Moralitas Individu, Ketaatan Aturan Akuntansi, Dan Efektivitas Pengendalian Internal Terhadap Kecenderungan Kecurangan (Fraud) Akuntansi Pada Lembaga Perkreditan Desa Di Kabupaten Buleleng. E-Journal S1 Ak Universitas Pendidikan Ganesha, Vol. 8(No. 2).

Coram, P., Ferguson, C., \& Moroney, R. (2008). Internal audit, alternative internal audit structures and the level of misappropriation of assets fraud. Accounting and Finance, 48(4), 543-559. https://doi.org/10.1111/j.1467-629X.2007.00247.x

Cressey, D. R. (1950). The Criminal Violation of Financial Trust. American Sociological Review, 15(6), 738-743. 
Dewi, G. A. K. R. S. (2017). Pengaruh Moralitas Individu Dan Pengendalian Internal Pada Kecurangan akuntansi (Studi Eksperimen pada Pemerintah Daerah Provinsi Bali). Jurnal Ilmiah Akuntansi, 1(1), 77-92. https://doi.org/10.23887/jia.v1i1.9984

Eka Putra, I. P. A. P., \& Latrini, M. Y. (2018). Pengaruh Pengendalian Internal, Budaya Organisasi, dan Moralitas pada Kecenderungan Kecurangan (Fraud) di LPD se-Kabupaten Gianyar. E-Jurnal Akuntansi, 25, 2155. https://doi.org/10.24843/eja.2018.v25.i03.p20

Eliza, Y. (2015). Pengaruh Asimetri Informasi, Moralitas Individu Dan Pengendalian Internal Terhadap Kecenderungan Kecurangan Akuntansi. Jurnal Akuntansi, 4(1), 86-100. https://doi.org/10.24843/eja.2019.v29.i02.p12

Fitri, Y., Nurazlina, N., \& A, A. (2016). Pengaruh Keefektifan Sistem Pengendalian Internal, Ketaatan Akuntansi, Asimteri Informasi Dan Moralitas Individu Terhadap Kecendrungan Kecurangan Akuntansi Dengan Perilaku Tidak Etis sebagai variabel intervening (Studi Empiris Pada Satuan Kerja Perangkat. Jurnal Online Mahasiswa Fakultas Ekonomi Universitas Riau, 3(1), 505-519.

Ghozali, I. (2013). Aplikasi Analisis Multivariate dengan Program SPSS (7th ed.). Badan Penerbit Universitas Diponegoro.

Hernandez, J. R., \& Groot, T. (2007). Corporate Fraud: Preventive Controls Which Lower Corporate Fraud. Amsterdam: Research Centre in Accounting.

Kohlberg, L. (1994). Tahap-tahap Perkembangan Moral. Kanisius.

Malau, S., \& Simanjuntak, J. (2019). 454 Kasus Korupsi Ditangani Sepanjang 2018. Tribun News.Com, 1.

Maroney, J. J., \& McDevitt, R. E. (2008). The Effects of Moral Reasoning on Financial Reporting Decisions in a Post Sarbanes-Oxley Environment. Behavioral Research in Accounting, 20(2), 89-110. https://doi.org/10.2308/bria.2008.20.2.89

Mazar, N., Amir, O. N., \& Ariely, D. A. N. (2008). Mazar, Amir, Ariely - The Dishonesty of Honest People. Journal of Marketing Research, XLV(December), 633-644.

Mudrajad, K. (2013). Metode Riset untuk Bisnis dan Ekonomi (Edisi 4.). Erlangga.

Mulia, H. K. M., Febrianto, R., \& Kartika, R. (2017). Pengaruh Moralitas Individu dan Pengendalian Internal terhadap Kecurangan: Sebuah Studi Eksperimental. Jurnal Akuntansi Dan Investasi, 18(2), 198-208. https://doi.org/10.18196/jai.180283

Rodiah, S., Ardianni, I., \& Herlina, A. (2019). Pengaruh Pengendalian Internal , Ketaatan Aturan Akuntansi , Moralitas Manajemen dan Budaya Organisasi Terhadap Kecurangan Akuntansi The Effect of Internal Control , Compliance with Accounting Rules , Management Morality and Organization Culture to Accoun. Jurnal Akuntansi \& Ekonomika, 9(1), 1-11.

Rodiah, S., \& Nahartyo, E. (2019). Knowledge Sharing Behaviour: the Effect of Psychological Safety on Balance Scorecard (BSC) Implementation. Journal of Accounting and Investment, 20(1). https://doi.org/10.18196/jai.2001106

Sekaran, U. (2009). J. W. and S. L. (2009). Research Methods for Business (ebook). Ltd., John Willey and Son.

Sholehah, N. L. H., Rahim, S., \& Muslim, M. (2018). Pengaruh Pengendalian Internal, Moralitas Individu dan Personal Culture Terhadap Kecurangan Akuntansi (Studi Empiris Pada OPD Provinsi Gorontalo). ATESTASI : Jurnal Ilmiah Akuntansi, 1(1), 40-54. https://doi.org/10.33096/atestasi.vli1.62

Welton, R. E., \& Lagrone, R. M. (1994). Promoting the moral development of accounting graduate students: An instructional design and assessment. Accounting Education, 3(1), 3550. https://doi.org/10.1080/09639289400000004

Wilopo, W. (2006). Analisis Faktor-faktor yang Berpengaruh terhadap Kecenderungan Kecurangan Akuntansi. The Indonesian Journal of Accounting Research, 9(3). 